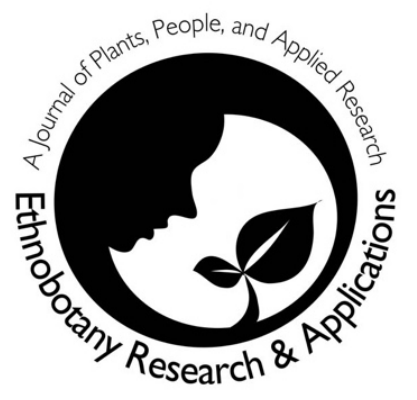

\title{
An Ethnobotanical Study on Native Plants of Bargarh District of Western Odisha, India in Relieving Urogenital Ailments
}

\author{
Alok Ranjan Sahu, Maninee Sahu, and Ain Raal
}

\section{Databases and Inventories}

\begin{abstract}
Background: This study focused on the ethnobotanical study on native plants of Bargarh district of western Odisha, India in relieving urogenital ailments.

Methods: The study area was visited regularly and close interaction were made with the senior tribal people involved with herbal medicines. During field work, interviews were conducted with local educated villagers, the herbal healer, old woman and medicinal plant vendors. A total of 42 healers form Binjhal tribes (Dravidian ethnic group) were interviewed from the10 selected blocks.
\end{abstract}

Results: A total of 28 species belong to 27 genera and 17 families were focused to have ethnobotanical significance towards urogenital ailments. Among the 28 plants species, $12(43 \%)$ trees species, eight $(29 \%)$ shrubs, six $(21 \%)$ herbs species and two (7) climber species were recorded. Various parts of these species were used by the natives, of these roots of highest number of species (8) were used, followed by leaves (7), barks (4), seeds and fruits of three species each; flowers, gums, corollas, and whole plants of one species each.

Conclusions: The present study showing that there was an abundance of huge knowledge within the different ethnic communities that were not explored yet. Due to lack of communication and systematic transmission among the young generation the ethnobotanical knowledge may be declined. Hence it is urgent to document the ethnobotanical knowledge of old age people. Several species such as Achyranthes aspera var. indica, Bauhinia racemosa, Cassia auriculata, Celosia argentea, Gloriosa superba, Terminalia bellirica, etc. can be further studied for their pharmacological activity and active compounds.

Keywords: ethnobotanicy, urogenital ailments, ethnic communities, Bargarh district.

\section{Correspondence}

Alok Ranjan Sahu ${ }^{1, *}$, Maninee $\mathrm{Sahu}^{2}$, and Ain Raal3,*

${ }^{1}$ Department of Botany, Vikash Degree College, Vikash Knowledge Hub, Barahaguda Canal Chowk, Bargarh, Odisha, India, e-mail: alok.btgene@gmail.com

${ }^{2}$ Department of Physics, Ghess College, Ghess, Odisha, India

${ }^{3}$ Institute of Pharmacy, Faculty of Medicine, University of Tartu, Tartu, Estonia

*Corresponding Author: (A.Raal): ain.raal@ut.ee, (A.R.Sahu): alok.btgene@gmail.com

\section{Ethnobotany Research \& Applications} 21:29 (2021)

\section{Background}

Since from ancient time, traditional systems of medicine have been used to treat various ailments in countries like China, Japan and India (Gilani \& Rahman 2005, Mukherjee \& Wahile 2006). Ayurveda is known as the mother of all therapies, and also known as Traditional Indian Medicine and the oldest healthcare system on earth. Ethnomedicine has 
evolved since the ancient time. Ethnobotanical information arises from complex interface among human beings and their adjacent environment that depends on a variety of factors such as local categorization system (Ellen 2009), communication through local language (Maffi 2005), human awareness and their cultural history (Leonti \& Casu 2013), faith and religion (Pieroni \& Quave 2005), use of social networks and information (Bandiera \& Rasul 2006). Ethnomedicinal research is the study of sole information concerning plant wealth and look for new resources for the preparation of herbal medicines, utilization of edible plants and plant parts, and other aspects of plants (Chandra et al. 2013, Kumar et al. 2021). Still traditional medicine is the main source for treating health related problems around the globe (Tefera \& Kim 2019). In spite of globalization and modernization, in developing countries nearly about $60-85 \%$ of the global population depends on traditional medicine for their health care purposes (Bhattacharyya et al. 2020). In the last few decades there was an increase on demand of herbal medicine globally. The previous reports were affirmed that out of 2,50,000 flowering plants in the world, only $>10 \%$ have been screened so far for their therapeutic influence, and still more than $90 \%$ remains unexplored (Rai et al. 2000, Ojha et al. 2020). Tribal groups store huge information on traditional herbal remedyies and this require to be properly documented (Karunamoorthi \& Tsehaye 2012). Ethnobotanical studies are the major sources for discovery of novel drugs from the plant species (Balunas \& Kinghorn 2005). India is considered as the primary manufacturer of medicinal plants and represents one of the best reservoirs of ethnobotanical assets (Maikhuri \& Gangwar 1993, Prakash et al. 2008). About $65 \%$ of the Indian population depends on traditional therapies (Timmermans 2003). The knowledge on conservation of medicinal plants and its use has made an interlinked between promoting the environmental conservation and native information (Cameron 2008). In order to fulfill the demand of rising population, in recent few years there is an increased interest on the use of medicinal plants to expand novel drugs and medicines (Gazzaneo et al. 2005, Ojha et al. 2020). So, the information on plants of their ethnomedicinal uses holds greater potential.

This communication projects the medicinal plants currently used by the native of Bargarh district, especially for urogenital complaints. The urogenital complaints may be hereditary or acquired. They may be in the nature of genetic disorders, drug-abuse, malnutrition, and even prevalent in particular environments and communities. Earlier researchers focused on flora and vegetation study of this area. Concerning useful plants, the classical approach for this area has been study of economic plants that could be grown in these areas for landscape protection and mostly agricultural and livestock raising activities. Our basis of specific questions to each local practitioner are that what are the plants they used to cure for urogenital ailments, what are the common names of those plants they were used, which pant parts they used for urogenital ailments, and what were the doses were asked and recorded to generate tables. In Odisha, there was very little publication related to use of medicinal plants for urogenital complaints (Panda \& Mishra 2011, Mahalik et al. 2015). In this manuscript we had pertinently tapped the information from the rural peoples of the study area. These, in turn, will prompt phytochemists and pharmacologists for evaluating them asd source modern medicine.

\section{Study Area}

Bargarh district is one of the ten districts of Western Odisha, eastern India (Figure 1). It lies between $20^{\circ}$ $43^{\prime}$ to $20^{\circ} 41^{\prime}$ North latitude and $82^{\circ} 39^{\prime}$ to $83^{\circ} 58^{\prime}$ East latitude. It is surrounded on the north by the state of Chhatisgarh and on the east by the district of Nawapara. The major rivers in the Bargarh district are tributaries of Mahanadi River, Ong (Ang), Jira and Jhaun rivers. There are natural springs at Nrushinghanath at the foot of Gandhamardhan hills of Padampur subdivision forming streams flowing in cascades down the steep hill side. The total geographical area of Bargarh district is $5837 \mathrm{~km}^{2}$, out of which $269.329 \mathrm{~km}^{2}$ of the area is covered by forest. Although agriculture is the main occupation of the tribal people, they are mostly dependent on forest and forest-based resources for supplementing their livelihood and health care. The physiography of the district gives a perfect platform for the tribal in sustaining their ethno cultural identity. Furthermore, the forests are dry deciduous and moist type. The population of the district is $14,81,255$ (census 2011). The district is inhabitant by tribes like Sahara, Binjhal, Kondh, Gond, Munda, Kuli, Oran, Kisan, Mirdha, Kharia and Parja. Out of these, Sahara, Binjhal, Kondh and Gond are the predominant tribes. The Binjhal (also known as Binjhwar) is a Dravidian ethnic group found mainly in five districts of Odisha i.e. Bargarh, Bolangir, Sonepur, Nuapada and Sambalpur. The Binjhal tribe is the second largest tribe belonging to Scheduled Tribe. As per the 2011 census report the total population of Binjhal tribe in Odisha is around 137040 including 68810 men and 68230 women. In Bargarh district, still agriculture is considered as the primary occupation of Binjhal tribe, many of them work as laborers in agricultural fields. As per the community people said that Binjhal is a combination of two words i.e. Bin and Jhal. 'Bin' in the local terms means 'without' and 'Jhal' means 'sweat'. Hence Binjhal are those who can 'work for long hours without sweating'. Thus the Binjhal of the 
Bargarh district are regarded as hard-workers and good agricultural laborers. In general, people having good strength and stamina, who can work in the field for long period of times without sweating (Sahu et al. 2010).
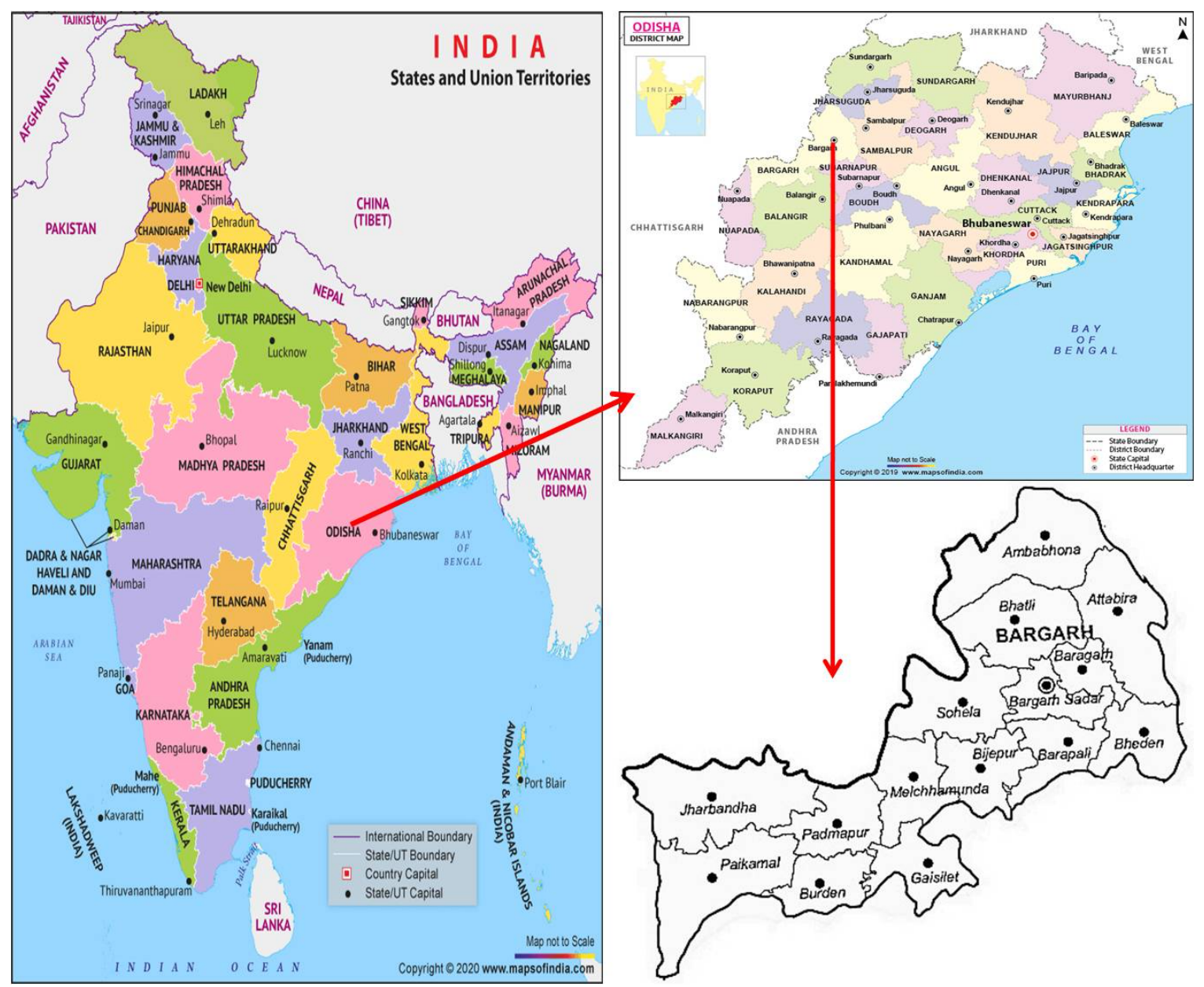

Figure 1. Map of India and Bargarh district.

\section{Materials and Methods}

Before the field worked started, in order to know the geographical location, demographic details, local name of plants, a literature survey was carried out in the study area (Sahu et al. 2010, Sahu et al. 2013, Sahu et al. 2016, Sen \& Behera 2003, Sen \& Behera 2008). The study area was visited in an interval of two months from 2010 to 2020 and close interactions were made with the senior tribal people involved with herbal medicines.

A total of 90 healers were interviewed and among them 42 well known healers from were selected for this study. These 42 healers form Binjhal tribes (Dravidian ethnic group) of different gender, educational qualification and years of experience were interviewed of 10 selected blocks of Bargarh district, western Odisha, India during January 2010 (Table 1). During field work, interviews were conducted with local educated villagers, the herbal healer called 'Kabiraj' or 'Vaidyas' (local physicians

in Indian System of Medicine), old woman and medicinal plant vendors.

Small rewards were given to participants. Moreover,120 common tribal people were also interviewed. Each use report was verified more than 10 times in 10-15 localities. For the ethnobotanical survey we used (Jain 1991, Pullaiah et al. 2017, Thakur et al. 2020. The local names of plants and doses of administration were documented in field. Further the local names were cross checked by using available previous report of Bargarh district (Sahu et al. 2010, Sahu et al. 2013, Sahu et al. 2016, Sen \& Behera 2003, Sen \& Behera 2008). The plant specimens were collected and identified using (Jain 1991, Saxena \& Brahmam 1994-1996). The plants were enumerated alphabetically with botanical name, family, voucher number, mode of uses and compiled in a tabular form. To collect the voucher specimen we followed the protocol as described by Mohanty (2018). The voucher specimens (No 003210) were deposited at the Department of Botany, Vikash Degree College, Bargarh, India. 
Table 1. Demographic characteristics of the healer of Bargarh district, western Odisha, India.

\begin{tabular}{|c|c|c|c|c|c|c|c|c|c|c|c|c|c|c|}
\hline \multirow[t]{2}{*}{$\begin{array}{l}\text { Locality } \\
\text { (Blocks) }\end{array}$} & \multicolumn{2}{|l|}{ Gender } & \multicolumn{3}{|c|}{ Educational Qualification } & \multicolumn{3}{|c|}{ Age (Years) } & \multicolumn{6}{|c|}{$\begin{array}{l}\text { Years of experience as healer } \\
\text { (Years) }\end{array}$} \\
\hline & Female & Male & Primary & $\begin{array}{l}\text { Secon } \\
\text {-dary }\end{array}$ & $\begin{array}{l}\text { Extra } \\
\text { teaching } \\
\text { quali- } \\
\text { fication }\end{array}$ & $\begin{array}{l}21- \\
40\end{array}$ & $\begin{array}{l}41- \\
60\end{array}$ & $\begin{array}{l}61- \\
80\end{array}$ & $\leq 10$ & $\begin{array}{l}11 \\
\text { to } \\
20\end{array}$ & $\begin{array}{l}21 \\
\text { to } \\
30\end{array}$ & $\begin{array}{l}31 \\
\text { to } \\
40\end{array}$ & $\begin{array}{l}41 \\
\text { to } \\
50\end{array}$ & $\begin{array}{l}>5 \\
1\end{array}$ \\
\hline Bheden & 2 & 3 & 5 & 0 & 0 & 2 & 2 & 1 & 0 & 0 & 2 & 1 & 2 & 0 \\
\hline Bijepur & 1 & 2 & 3 & 1 & 0 & 0 & 2 & 1 & 0 & 1 & 1 & 1 & 0 & 0 \\
\hline Sohela & 2 & 3 & 5 & 2 & 1 & 1 & 2 & 2 & 1 & 2 & 1 & 0 & 0 & 1 \\
\hline Jharbandha & 3 & 2 & 5 & 0 & 0 & 2 & 2 & 1 & 1 & 0 & 1 & 2 & 1 & 0 \\
\hline Paikamal & 2 & 4 & 6 & 0 & 0 & 3 & 2 & 1 & 1 & 2 & 0 & 1 & 2 & 0 \\
\hline Bhatli & 1 & 2 & 3 & 1 & 0 & 2 & 1 & 0 & 0 & 0 & 1 & 1 & 1 & 0 \\
\hline Padmapur & 1 & 3 & 4 & 2 & 1 & 1 & 2 & 1 & 0 & 1 & 1 & 2 & 0 & 0 \\
\hline Gaisilet & 0 & 2 & 2 & 1 & 0 & 1 & 1 & 0 & 0 & 0 & 0 & 1 & 1 & 0 \\
\hline $\begin{array}{l}\text { Melchha- } \\
\text { munda }\end{array}$ & 2 & 2 & 4 & 1 & 1 & 2 & 1 & 1 & 0 & 0 & 2 & 1 & 1 & 0 \\
\hline Ambabhona & 2 & 3 & 5 & 0 & 0 & 2 & 1 & 2 & 1 & 1 & 2 & 0 & 0 & 1 \\
\hline Totals & 16 & 26 & 42 & 8 & 3 & 16 & 16 & 10 & 4 & 7 & 10 & 13 & 6 & 2 \\
\hline
\end{tabular}

\section{Results and Discussion}

In this manuscript we reported a total of 28 species of medicinal plants belong to 27 genera and 17 families (Table 2, Figure 2). The highest numbers of plant species were contributed from Fabaceae (Abrus precatorius L., Bauhinia racemosa Lam, Butea monosperma (Lam.) Taub, Cassia auriculata (L.) Roxb., Tamarindus indica L.), Malvaceae (Bombax ceiba L., Gossypium herbaceum L., Hibiscus rosa-sinensis L., Sida acuta Burm. f.) and Lamiaceae (Gmelina arborea Roxb., Tectona grandis L. f., Vitex nergundo L.); two species each from two families, Amaranthaceae (Achyranthes aspera var. indica L., Celosia argentea L.), and Moraceae (Ficus hispida L. f., Ficus religiosa L.). The remaining ten families contributed one each (Figure 3). For categorization of plants the APG-IV system of plant classification was used (Mohanty 2018). Among the 28 plants species, $12(43 \%)$ trees species, eight $(29 \%)$ shrubs, six $(21 \%)$ herbs species and two $(07 \%)$ climber species were recorded (Figure 4). Various parts of these species were used by the local practitioners of Binjhal tribe (Dravidian ethnic group), mostly roots number (8 species) were used, followed by leaves (7), barks (4), seeds and fruits of three species each; flowers, gums, corollas, and whole plant of one species each (Figure 5).

Achyranthes aspera var. indica was used to cure arthritis, asthma, dandruff, fistula, hepatitis, insect bite, leprosy, piles, snake bite, wound (Dey 2011). The bark of Bombax ceiba was used to cure joint break (Kumar et al. 2021). Seeds and flowers of Butea monosperma were used in the treatment of dysentery and ring worm (Kumar et al. 2021). Several species as listed in Table 2, such as Aloe vera, Azadirachta indica, Ricinus communis, Withania somnifera, Phyllanthus emblica, and Lawsonia inermis have a long tradition of use in folk medicine, their composition and effects have been fairly well studied and they are recognized in various countries as medicinal plants (Table 2). Previous experience in studying the biological activity of Estonian and Vietnamese medicinal plants shows that the experience of folk medicine is often confirmed by research of their biological activity (Raal et al. 2015, Nguyen et al. 2018, Tran et al. 2019). Therefore, it is important to pay attention to those plants that have so far been little scientifically studied; there are no studies about biological activity and clinical trials of Bauhinia racemosa, and Madhuca longifolia var. latifolia. The species such as Bauhinia racemosa, Cassia auriculata, Celosia argentea, Gloriosa superba, Terminalia bellirica, etc. have been very little studied in terms of chemical composition and biological activity.

There were no earlier report available regarding the traditional uses of medicinal plants to cure urogenital complaints in the Binjhal tribes (Dravidian ethnic group) in this study sites. Panda and Mishra (2011) reported the uses of Coix aquatica Roxb. to cure painful urination and menstrual complaints, and Limnophili arugosa (Roth) Merr. to cure urinary burning by the local healer of South Odisha. Mahalik et al. (2015) reported about the use of 26 plant species in the treatment of urinary disorders in Dhenkanal district of Odisha. 
Table 2. Medicinal plants and their traditional uses for the treatment of urogenitial complaints by the natives of Bargarh District, Western Odisha.

\begin{tabular}{|c|c|c|c|c|c|}
\hline Botanical Name & $\begin{array}{l}\text { Local Name } \\
\text { as per the } \\
\text { Dravidian } \\
\text { ethnic group } \\
\text { (Binjhal tribe) }\end{array}$ & Family & $\begin{array}{l}\text { Voucher } \\
\text { number }\end{array}$ & $\begin{array}{l}\text { Plants parts with ethnomedicinal uses for } \\
\text { urogenital complaints }\end{array}$ & $\begin{array}{l}\text { No. of papers indexeed } \\
\text { by Web of Science*: } \\
\text { total/chemical } \\
\text { composition/biological } \\
\text { activity/clinical trial }\end{array}$ \\
\hline Abrus precatorius $\mathrm{L}$. & Gunj & Fabaceae & ARS/BGH-03 & $\begin{array}{l}\text { White seeds kept in unboiled cow milk for the period } \\
\text { of overnight and the seed is given to woman in the } \\
\text { morning at the end of menstruation cycle for } \\
\text { preventing conception. }\end{array}$ & $376 / 4 / 7 / 1$ \\
\hline $\begin{array}{l}\text { Achyranthes aspera var. } \\
\text { indica L. }\end{array}$ & Latkana & Amaranthaceae & ARS/BGH-09 & $\begin{array}{l}\text { Root paste is applied externally on abdomen for } \\
\text { quick delivery. }\end{array}$ & $18 / 1 / 0 / 0$ \\
\hline Aloe vera Mill. & Gheekuanri & Liliaceae & ARS/BGH-20 & $\begin{array}{l}\text { About } 5 \mathrm{gm} \text { of leaf juice along with turmeric and } \\
\text { black salt is taken twice daily in empty stomach to } \\
\text { cure irregular periods. }\end{array}$ & $3111 / 45 / 24 / 114$ \\
\hline Azadirachta indica A. Juss. & Lim & Meliaceae & ARS/BGH-32 & $\begin{array}{l}\text { About } 20 \text { gm each stem bark of Azadirachta indica } \\
\text { A. Juss. and Acacia nelotica is boiled in three } \\
\text { glasses of water and filtered. The filtrate (one glass) } \\
\text { is taken in the morning in empty stomach for one } \\
\text { week to cure white discharge }\end{array}$ & $3913 / 70 / 75 / 10$ \\
\hline Bauhinia racemosa Lam. & Kuler & Fabaceae & ARS/BGH-37 & $\begin{array}{l}\text { Leaf extract mixed with sugar and milk is given four } \\
\text { times a day for normal urination. }\end{array}$ & $46 / 1 / 0 / 0$ \\
\hline Boerhavia diffusa L. & Gadhapurni & Nyctaginaceae & ARS/BGH-38 & $\begin{array}{l}\text { About } 15 \mathrm{ml} \text { of whole plant decoction is given once a } \\
\text { day in the early morning for fifteen days for the } \\
\text { treatment of Leucorrhoea }\end{array}$ & $107 / 3 / 1 / 0$ \\
\hline Bombax ceiba L. & Semel & Malvaceae & ARS/BGH-39 & $\begin{array}{l}\text { About } 1 \mathrm{gm} \text { of pasty mass of fleshy roots of young } \\
\text { plant mixed with } 2 \mathrm{ml} \text { of unboiled cow milk is taken } \\
\text { once a day in the early morning for a week by } \\
\text { women to regulate irregular menstruation. }\end{array}$ & $155 / 3 / 0 / 0$ \\
\hline $\begin{array}{l}\text { Butea monosperma } \\
\text { (Lam.)Taub. }\end{array}$ & Palsa & Fabaceae & ARS/BGH-44 & $\begin{array}{l}\text { A cup of flowers decoction is drunk in the morning } \\
\text { for seven days to regulate menstrual cycle. }\end{array}$ & $234 / 3 / 0 / 0$ \\
\hline
\end{tabular}




\begin{tabular}{|c|c|c|c|c|c|}
\hline $\begin{array}{l}\text { Cassia auriculata (L.) } \\
\text { Roxb. }\end{array}$ & Radhachura & Fabaceae & ARS/BGH-53 & $\begin{array}{l}\text { Gum of the plant is mixed in latex of Ficus } \\
\text { benghalensisand about } 20 \mathrm{ml} \text { of this mixture is } \\
\text { given four times a day for about a fortnight to expel } \\
\text { urinary stone. }\end{array}$ & $145 / 1 / 1 / 0$ \\
\hline Celosia argentea L. & Sirel & Amaranthaceae & ARS/BGH-59 & $\begin{array}{l}\text { Root paste of the plant is applied locally on stomach } \\
\text { for urinary stone for a month. Leaf extract of the } \\
\text { plant is consumed for } 15 \text { consecutive days to expel } \\
\text { stone from kidneys. }\end{array}$ & $212 / 1 / 3 / 0$ \\
\hline Ficus racemosa L. & Dumer & Moraceae & ARS/BGH-104 & $\begin{array}{l}\text { Boiled green fruits given to mother as a } \\
\text { glactogogue for better milk. }\end{array}$ & $169 / 3 / 1 / 1$ \\
\hline Ficus religiosa L. & Pipal & Moraceae & ARS/BGH-105 & $\begin{array}{l}\text { About } 10 \mathrm{gm} \text { of bark is taken with one glass of } \\
\text { water twice daily for one month to cure white } \\
\text { discharge. }\end{array}$ & $260 / 1 / 1 / 0$ \\
\hline Gloriosa superba L. & Puraful & Colchicaceae & ARS/BGH-107 & $\begin{array}{l}\text { Paste of roots and tubers prepared in water is } \\
\text { applied on hand palms and soles of feet of women } \\
\text { to help expel the delayed placenta after delivery. }\end{array}$ & $181 / 1 / 4 / 0$ \\
\hline Gmelina arborea Roxb. & Gambher & Lamiaceae & ARS/BGH-109 & $\begin{array}{l}\text { Fruit powder is homogenized with milk and cow } \\
\text { ghee. About } 25 \mathrm{ml} \text { of it is taken orally per day during } \\
\text { the } 5^{\text {th }} \text { month of pregnancy for better settlement of } \\
\text { foetus. }\end{array}$ & $469 / 12 / 1 / 0$ \\
\hline Gossypium herbaceum L. & Kapa & Malvaceae & ARS/BGH-110 & $\begin{array}{l}\text { Rice grains are dipped in water for overnight. Root } \\
\text { powder of this plant is mixed in this water. Two } \\
\text { spoonfuls of this is given daily in the morning to the } \\
\text { patients suffering from leucorrhoea. }\end{array}$ & $112 / 1 / 1 / 0$ \\
\hline Hibiscus rosa-sinensis L. & Mandar & Malvaceae & ARS/BGH-115 & $\begin{array}{l}\text { 5-6 young leaves extract was taken orally daily for } \\
20-30 \text { days to cures leucorrhoea. }\end{array}$ & $490 / 7 / 3 / 1$ \\
\hline Ipomoea aquatica Forssk. & Kalam Sag & Convolvulaceae & ARS/BGH-118 & $\begin{array}{l}\text { About } 20-25 \mathrm{ml} \text { of leaf extract was taken orally for } 7 \\
\text { days regularly before the probable date of delivery } \\
\text { to accelerate easy delivery. }\end{array}$ & $396 / 0 / 2 / 0$ \\
\hline Lawsonia inermis $\mathrm{L}$. & Benjati & Lythraceae & ARS/BGH-123 & $\begin{array}{l}\text { About } 100 \mathrm{ml} \text { of leaf juice is taken orally as } \\
\text { contraceptive. It is effective in preventing } \\
\text { conception as long as the woman consumes it. }\end{array}$ & $427 / 10 / 5 / 6$ \\
\hline
\end{tabular}




\begin{tabular}{|c|c|c|c|c|c|}
\hline $\begin{array}{l}\text { Madhuca longifolia var. } \\
\text { latifolia (Roxb.) A. Chev }\end{array}$ & Mahul & Sapotaceae & ARS/BGH-126 & $\begin{array}{l}\text { A glass of decoction of corollas is taken orally to } \\
\text { treat dysuria till cure. }\end{array}$ & $235 / 10 / 0 / 0$ \\
\hline Phyllanthus emblica L. & Anla & Phyllanthaceae & ARS/BGH-95 & $\begin{array}{l}\text { Fruit powder and sugar mixed properly mixed in } \\
\text { ghee and honey are consumed by men as an } \\
\text { aphrodisiac. }\end{array}$ & $816 / 12 / 6 / 12$ \\
\hline Ricinus communis L. & Jada & Euphorbiaceae & ARS/BGH-143 & $\begin{array}{l}\text { Leaf smeared with groundnut oil is warmed and ties } \\
\text { on abdomen to relieve menstrual pains. }\end{array}$ & $4164 / 75 / 51 / 4$ \\
\hline Sida acuta Burm. f. & Bajarmuli & Malvaceae & ARS/BGH-179 & $\begin{array}{l}\text { About } 10 \mathrm{gm} \text { of root powder mixed in milk or honey } \\
\text { and taken orally to cures bleeding leucorrhoea. }\end{array}$ & $98 / 0 / 1 / 0$ \\
\hline Tamarindus indica L. & Tentel & Fabaceae & ARS/BGH-190 & $\begin{array}{l}\text { The seeds are soaked overnight, then the paste of } \\
\text { those soaked seed (two spoons) along with one } \\
\text { glass of milk is taken twice daily to cure white } \\
\text { discharge. }\end{array}$ & $754 / 21 / 6 / 2$ \\
\hline Tectona grandis L. f. & Sagun & Lamiaceae & ARS/BGH-191 & $\begin{array}{l}\text { Seed powder is soaked in cold water. About half } \\
\text { galas of it taken orally to cures strangury caused } \\
\text { during sunny days. }\end{array}$ & $1195 / 23 / 3 / 0$ \\
\hline $\begin{array}{l}\text { Terminalia bellirica } \\
\text { (Gaertn.) Roxb. }\end{array}$ & Behera & Combretaceae & ARS/BGH-194 & $\begin{array}{l}\text { About } 2 \mathrm{gm} \text { of stem bark paste is prescribed to } \\
\text { women with hot water twice a day after food } \\
\text { continuously } 10 \text { days as a cure for leucoderma. }\end{array}$ & $113 / 2 / 1 / 0$ \\
\hline Vitex negundo L. & Nirgundi & Lamiaceae & ARS/BGH-203 & Root paste is applied on abdomen for easy delivery. & $467 / 10 / 4 / 1$ \\
\hline $\begin{array}{l}\text { Withania somnifera (L.) } \\
\text { Dunal }\end{array}$ & Aswagandha & Solanaceae & ARS/BGH-204 & $\begin{array}{l}\text { About } 20 \mathrm{ml} \text { of root extract of this plant was taken } \\
\text { orally once a day for a period of two weeks, that } \\
\text { helps to arouse sexual desire in both women and } \\
\text { men. }\end{array}$ & $1800 / 11 / 24 / 15$ \\
\hline Ziziphus mauritiana Lam. & Buro & Rhamnaceae & ARS/BGH-210 & $\begin{array}{l}\text { Stem bark paste is taken twice a day after food as a } \\
\text { cure for abdominal pain during pregnancy. }\end{array}$ & $330 / 6 / 4 / 0$ \\
\hline
\end{tabular}



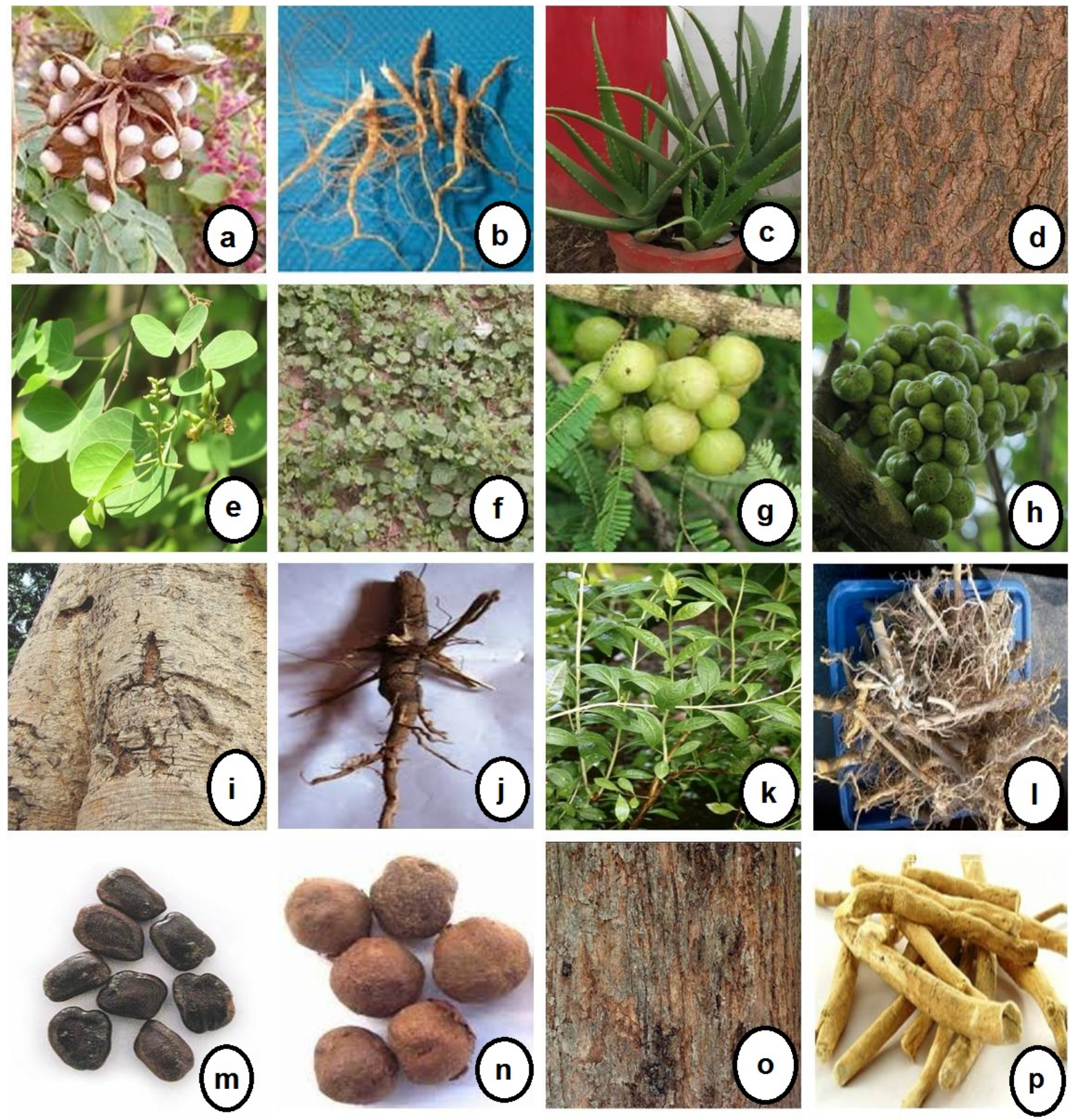

Figure 2. Photograph of Abrus precatorius L. seeds (a), Achyranthes aspera var. indica L. roots (b), Aloe vera Mill. (c), Azadirachta indica A. Juss. Bark (d), Bauhinia racemosa Lam. leaves (e), Boerhavia diffusa L. (f), Phyllanthus emblica L. Fruits (g), Ficus racemosa L. Young fruits (h), Ficus religiosa L. bark (i), Gossypium herbaceum L. root (j), Lawsonia inermis L. leaves (k), Sida acuta Burm. f. roots (I), Tamarindus indica L. Seeds (m), Tectona grandis L. f. seeds (n), Terminalia bellirica (Gaertn.) Roxb. Bark (o), Withania somnifera (L.) Dunal roots(p).

\section{Conclusion}

This study provides evidence that the tribal people of Bargarh district were sacred with the huge knowledge of ethnobotanical uses of plants of their surroundings.

The present study exposed that there was an abundance of huge knowledge within the different ethnic communities that were not explored yet and which need more special attention in next studies. Majority of the people of the study area depend on plant-based medicine for their common health problems such as common colds, dysentery, toothache, scorpion and insect bites, skin diseases, etc. Young generation people hesitated to pursue such kind of traditional practices. Due to lack of communication and systematic transmission among the young generation the ethnobotanical knowledge may be declined. Several species can be further studied for their pharmacological activity and active compounds. 


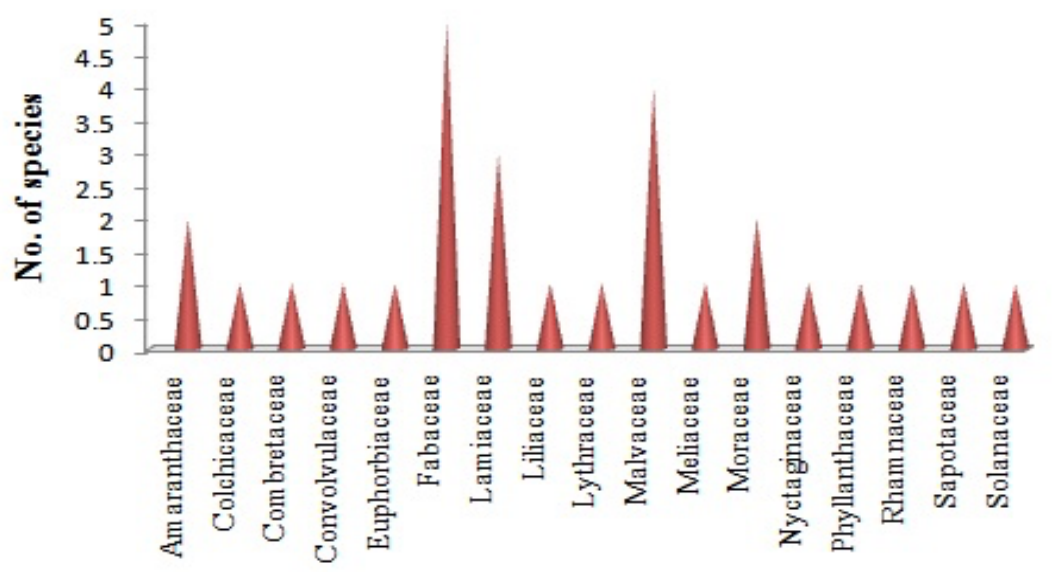

Family

Figure 3. Family-wise distribution of medicinal plant species.

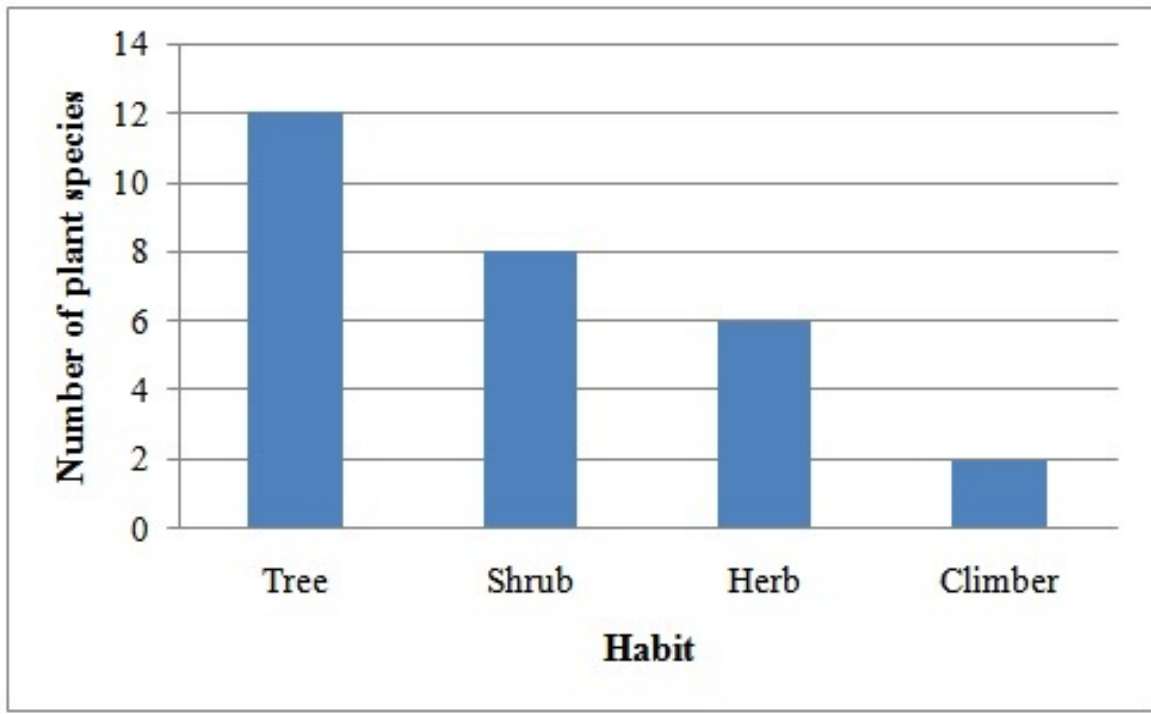

Figure 4. Diversity of plant species by habit.

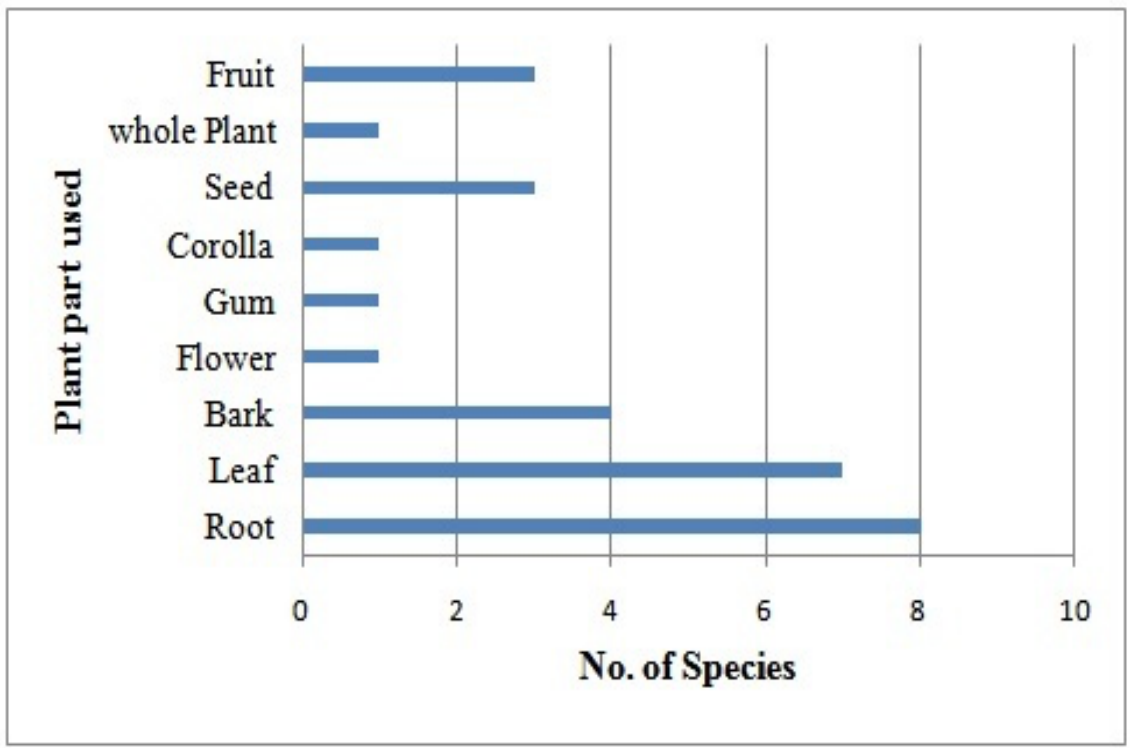

Figure 5. Statistical representation of used parts for relieving Urogenital ailments of the study sites. 
The local population of Bargarh district used modern medicines for the cure of ailments other than urogenital complaints. But for urogenital complaints, they were generally hesitating to go use allopathic or medicaments from hospitals. Though the World Health Organization encourages the use of traditional herbal medicines, which have been proven to be safe and effective for healthcare needs (Anonymous 1993), it appears essential to assess the medicinal effectiveness of such plants. Such attempts will help integrate the folk medicines with the modern system of medicine. There are many sexual hazards in tribal population, such as age at menarche and menopause, adolescent sterility, family structure, varying and changing socioeconomic conditions. Awareness programs are necessity in the study area.

\section{Declarations}

List of abbreviations: The article does not contain abbreviations.

Ethics approval and consent to participate: The study does not include ethical conflict. No animal experiments were used. This article is not in conflict with the Nagoya Protocol on Access and Benefit Sharing. All participants provided oral prior consent before the interviews.

Consent for publication: Not applicable.

Availability of data and materials: Not applicable. Competing interests: Not applicable.

Funding: No funding.

Authors' contributions: Dr. Alok Ranjan Sahu conceived the project, designed the experiment, conducted the field survey interpreted the results, and contributed to the writing of the manuscript. Mrs. Maninee Sahu helped the first author during field survey, analyzed the data and contributed to the writing of the manuscript. Prof. Ain Raal helped two other authors to analyse the results of the study, he contributed to the writing and correcting and submission of the manuscript.

\section{Acknowledgements}

The authors are especially thankful to the tribal and local health healers of Bargarh district for their cooperation and voluntarily shared a wealth of their accumulated knowledge regarding the ethnomedicinal practices of their communities and for their hospitality.

\section{Literature cited}

Balunas MJ, Kinghorn AD. 2005. Drug discovery from medicinal plants. Life Science 78:431-441.

Bandiera O, Rasul I. 2006. Social Networks and Technology Adoption in Northern Mozambique. Economy Journal 116:869-902.
Bhattacharyya R, Medhi KK, Borthakur S, Kand Borkataki S. 2020. An Ethnobotanical Study of Medicinal Plants used against Jaundice by Tea Tribes of Morigaon District, Assam (India). Journal of Natural Remedies 20:16-28.

Cameron MM. 2008. Modern desires, knowledge control, and physician resistance: Regulating Ayurvedic medicine in Nepal. Asian Medicine 4:86112.

Chandra K, Nautiyal B, Nautiyal MC. 2013. Ethnobotanical Resources as Supplementary Foods and Less Known Wild Edible Fruits in District Rudraprayag, Uttarakhand, India. Journal of Human Ecology 42:259-271.

Dey A. 2011. Achyranthes aspera - Phytochemical and Pharmacological aspects. International Journal of Pharmaceutical Sciience Review and Research 9:72-82.

Ellen RF. 2009. Classification. In The Routledge Encyclopedia of Social and Cultural Anthropology; Barnard, A., Spencer, J., Eds.; Routledge: London, UK; New York, NY, USA, pp. 129-133.

Gazzaneo LR, Paiva de Lucena RF, Paulino de Albuquerque U. 2005. Knowledge and use of medicinal plants by local specialists in a region of Atlantic Forest in the state of Pernambuco (Northeastern Brazil). Journal of Ethnobiology and Ethnomedicine 1:9.

Gronhaug TE, Glæserud S, Skogsrud M, Ballo N, Bah S, Diallo D, Paulsen BS. 2008. Ethnopharmacological survey of six medicinal plants from Mali, West-Africa. Journal of Ethnobiology and Ethnomedicine 4:26. https://doi.org/10.1186/17464269-4-26.

Jain SK. 1991. Dictionary of Indian Flora Medicines and Ethnobotany, Deep Publication, New Delhi, 311 p.

Karunamoorthi K, Tsehaye E. 2012. Ethnomedicinal knowledge, belief and self-reported practice of local inhabitants on traditional antimalarial plants and phytotherapy. Journal of Ethnopharmacology 141:143-150.

Kumar M, Rawat S, Nagar B, Kumar A, Pala NA, Bhat JA, Bussmann RW, Cabral-Pinto M, Kunwar R. 2021. Implementation of the Use of Ethnomedicinal Plants for Curing Diseases in the Indian Himalayas and Its Role in Sustainability of Livelihoods and Socioeconomic Development. International Journal of Environenvironmental Research and Public Health 18:1509. doi:10.3390/ijerph18041509

Leonti M, Casu L. 2013. Traditional medicines and globalization: Current and future perspectives in ethnopharmacology. Frontiers in Pharmacology 4:92.

Lucy H, Edgar JD.1999. Medicinal plants: A reemerging health aid, division of life sciences UNESCO. 
Maffi L. 2005. Linguistic, cultural, and biological diversity. Annual Review of Anthropology 34:599617.

Mahalik G, Sahoo S, Satapathy KB. 2015.Ethnobotanical Survey of Plants used in Treatment of Urinary disorders in Dhenkanal district of Odisha, India. IOSR Journal of Environmental Science, Toxicology and Food Technology 9:58-63.

Maikhuri RK, Gangwar AK. 1993. Ethnobiological notes on the Khasi and Garo tribes of Meghalaya, Northeast India. Econ. Bot. 47:345. https://doi.org/10.1007/BF02907348.

Mohanty CR. 2018. Textbook of Plant Systematics, Kalyani Publisher, New Delhi.

Mohanty P, Mahalik G. 2020. A Review on Ethnobotanical Survey of Medicinal Plants used against Urinary Tract Infections. Indian Journal of Natural Sciences 10:20465- 20470.

Nguyen HT, Ho DV, Nguyen PDQ, Vo HQ, Do TT, Raal A. 2018. Cytotoxic evaluation of compuonds isolated from the aerial parts of Hedyotis pilulifera and methanol extract of Inonotus obliquus. Natural Product Communications 13:939-941.

Ojha SN, Tiwari D, Anand A, Sundriyal RC. 2020. Ethnomedicinal knowledge of a marginal hill community of Central Himalaya: diversity, usage pattern, and conservation concerns. Journal of Ethnobiology and Ethnomedicine16:29. https://doi.org/10.1186/s13002-020-00381-5.

Panda A, Mishra MK. 2011. Ethnomedicinal survey of some wetland plants of South Orissa and their conservation. Indian Journal of Traditional Knowledge10:296-303.

Pieroni A, Quave C. 2005. Traditional pharmacopoeias and medicines among Albanians and Italians in southern Italy: A comparison. Journal of Ethnopharmacology 101:258-270.

Prakash JW, Anpin Raja RD, Asbin Anderson N, Williams C, Regini GS, Bensar K, Rajeev R, Kiruba S, Jeeva S, Das SSM. 2008. Ethnomedicinal plants used by Kani tribes of Agasthiyarmalai biosphere reserve, southern Western Ghats. Indian Journal of Traditional Knowledge 7:410-413.

Pullaiah T, Krishnamurthy KV, Bahadur B. 2017. Ethnobotany of India, Vol. 1-5. CRC Press.

Raal A, Nguyen TH, Ho VD, Do TT. 2015. Selective cytotoxic action of Scots pine (Pinus sylvestris L.) needles extract in human cancer cell lines. Pharmacognosy Magazine 11:290-295.

Rai LK, Prasad P, Sharma E. 2000. Conservation threats to some important medicinal plants of Sikkim Himalaya. Biology and Conservation 93:27-33.

Sahu AR, Behera N, Mishra SP. 2010. Use of Ethnomedicinal Plants by Natives of Bargarh District of Orissa, India. Ethnobotanical Leaflets 14:889-910.
Sahu AR, Nayak AK, Panigrahi SK. 2013. Survey of some important ethno-medicinal plants of Sohela Block, Western Odisha, India. Life Sciences Leaflets11:1-9.

Sahu AR, Panigrahi J, Mishra SP. 2016. A preliminary report on the Ethnoveterinary Medicinal Plants of Bargarh District, Western Odisha, India. In: Conservation, Cultivation, Diseases and Therapeutic Importance of Medicinal and Aromatic Plants,Chourasia HK and Roy AK (eds.). Today \& Tomorrows Printers and Publishers, New Delhi, Chapter-19, pp.315-325.

Saxena HO, Brahmam M. 1994-96. The Flora of Orissa, Vol. 1-4. Regional Research Laboratory and Forest Development Corporation of Orissa, Bhubaneswar.

Sen SK, Behera LM. 2008. Ethnomedicinal plants used by the tribals of Bargarh district to cure diarrhoea and dysentery. Indian Journal of Traditional Knowledge 7:425-428.

Sen SK, Behera LM. 2003. Ethnomedicinal plants used against skin diseases at Bargarh district in Orissa (India). Ethnobotany 15:90-96.

Thakur AK, Bassi SK, Sood SK. 2020. Ethnobotany. S. Dinesh \& Co., Jalandhar.

Timmermans K. 2003. Intellectual property right and traditional medicine: policy dilemmas at the interface. Social Science and Medicine 57:745-756.

Tran LTT, Ho DV, Le DV, Phan KV, Nguyen HT, Raal A. 2019. Apoptosis-inducing effect of pogostemin A isolated from the aerial parts of Pogostemon auricularius against the humal lung cancer cells. Journal of Biologically Active Products from Nature 9:320-327. 